\title{
Zpráva o konferenci Czech and Slovak Scenography for Shakespeare
}

\author{
Amálie Bulandrová
}

Czech and Slovak Scenography for Shakespeare. 6.-7. listopadu 2015, School of Drama, Music and Screen, University of Hull.

Začátkem listopadu 2015 proběhla v britském univerzitním městě Hull mezinárodní teatrologická konference zaměřená na téma československé scénografie v inscenacích her Williama Shakespeara. Jejími pořadateli byli zástupci katedry School of Drama z University of Hull, Pavel Drábek a Christian Billing, díky nimž se zde setkali divadelní vědci z České republiky, Slovenska, USA a Velké Británie.

Cílem konference bylo ukázat a zpřístupnit mezinárodní akademické obci množství různých zpracování jevištního výtvarnictví a scénografických řešení v inscenacích her Williama Shakespeara za poslední století a půl. Dalším záměrem tohoto setkání odborníků bylo shromáždit uvedené příspěvky jako podklady pro zamýšlený sborník, který představí genealogii scénografických realizací jednotlivých her i žánrů, spolu s nejrůznějšími nuancemi porozumění vybraným hrám.

Tato konference, která vznikla jako součást širokého mezinárodního výzkumného projektu dvou kontinentů, zahrnujícího umělecké výstavy, monografie (jak samotných scénografů, tak dílčích historicko-estetických stylů) a jednu hromadnou sbírku esejů, tedy zároveň fungovala i jako mezinárodní výměna analýz a výzkumů inscenovaných Shakespearových her a jejich inovačních scénografických řešení v jed- notlivých kulturních prostředích a v různých historických obdobích.

A proč zrovna československé jevištní výtvarnictví a Shakespeare? Důvodem je dlouholetý status české a slovenské scénografie uznávané po celém světě a mající - stejně jako dílo Williama Shakespeara - normativní vliv na nadnárodní zprostředkovávání divadelního a dramatického umění. A jelikož česká a slovenská scénografie (nejen) minulého století oplývala takovými osobnostmi, jakými byli Vlastislav Hofman, Josef Svoboda, František Tröster, Jaroslav Malina a mnoho dalších, je o její reflexi ve světě zájem i v současnosti, o čemž mimo jiné vypovídá i koncepčně rozsáhlý program zmíněného setkání.

Program zahájil v pátek 6. listopadu Christian M. Billing z domácí University of Hull, po jehož přivítání a úvodní řeči přednesl svůj př́spěvek Pavel Drábek. Přední český teatrolog hovořil o historickém kontextu inscenování děl Williama Shakespeara na území dnešního Slovenska a České republiky, na jehož pozadí vznesl základní otázky: Jak nám může scénografie pomoci porozumět Shakespearovi? Jak lze aplikovat sémiotické myšlení a analytické postupy na scénografii? Co nám může Shakespeare říct o konkrétním kulturním kontextu, ve kterém je inscenován? Je 
možné recepci děl Williama Shakespeara pokládat za národní identitu? A lze pojmenovat charakteristické prvky/rysy inscenování Shakespeara v Čechách?

Pokud to nebyly příspěvky samotné, které se k těmto i obecnějším otázkám porůznu vztahovaly, pak se k nim jistě vyjadřovaly průběžné diskuze, vyvolávající další podnětné, obdobně tematizované debaty.

Jako další vystoupila Šárka Havlíčková Kysová z Masarykovy univerzity a představila vlastní výzkum inscenování shakespearovských oper v brněnském Státním divadle v šedesátých letech 20. století, se zaměřením na scénografická řešení. V př́ímé návaznosti na toto pojednávané téma vystoupila další ze zástupkyň brněnské teatrologie, Kateřina Lukáčová. Svým příspěvkem obeznámila posluchače se závěry vlastní komparativní analýzy dvou scénografických řešení opery Falstaff, inscenované v brněnském Státním divadle v letech 1953 a 1973. Jmenované svými příspěvky otevřely jako jediné účastnice konference problematiku scénografie inscenací shakespearovských oper, jež zahrnovala i polemiku nad otázkou, do jaké míry zůstává Shakespeare Shakespearem v operních produkcích, a v čem se vlastně operní scénografie diametrálně odlišuje od činoherní.

Následující blok příspěvků započal Dan Matthews z americké Ohio State University, který se zabývá českou shakespearovskou scénografií v trojdimenzionálním prostoru, tedy její skulpturální a digitální reprodukcí a možnostmi jejího vystavení. Svůj příspěvek Matthews doplnil ukázkami z vlastní divadelní praxe i z (před pár měsíci proběhnuvšího) 13. ročníku Pražského Quadriennale scénografie a jevištního prostoru.

Psycho-plastický narativní prostor v tvorbě Josefa Svobody tvořil hlavní téma stu- die Chrise Berchilda z Indiana University. Přednášející svým výzkumem naznačil, že Svobodova scénografie shakespearovských inscenací může být chápána ve smyslu prvních příkladů tzv. akční scénografie, později užívané především Jaroslavem Malinou.

Druhý blok prvního konferenčního dne zakončil jeden $\mathrm{z}$ hlavních pořadatelů, Christian M. Billing. Analýzou scénografické realizace Josefa Svobody navržené pro inscenaci Shakespearovy tragédie Král Lear režiséra Endre Martona v mad'arském Národním divadle v roce 1964 poukázal na možné zpơsoby čtení a porozumění politickému kontextu vzniku scénografických výprav.

Před závěrečnou diskuzí vystoupila před řečnický pult Zuzana Koblišková, která na příkladech scénografické sbírky Múzea Divadelného ústavu v Bratislavě, jejíž je kurátorkou, pohovořila o faktech, kontextu a estetice slovenské scénografie vytvořené pro inscenace her Williama Shakespeara realizované mezi lety 1920 a 1989. Za Dagmar Inštitorisovou z Panevropské vysoké školy v Bratislavě, která se konference nemohla zúčastnit, následně přečetla Zuzana Koblišková i analýzu scénografické tvorby Jozefa Cillera.

Společnou debatou o principech, praxi a historii české a slovenské scénografické tvorby pro inscenace Shakespearových her oficiálně skončil první diskusní den, jehož pokračování zahájila v sobotu 7. listopadu Vlasta Koubská z Divadelní fakulty Akademie múzických umění v Praze. Vlasta Koubská svým příspěvkem vymezila význam tvorby českých scénografů první poloviny 20. století - Vlastislava Hofmana a Františka Muziky, přičemž značnou část svého pojednání věnovala Hofmanovým scénografickým návrhům k Shakespearově Bouri . 
Jana Bžochová-Wild, zástupkyně Vysoké školy múzických umění v Bratislavě, následně představila historii, kontext a vývoj inscenování Shakespearova Hamleta na Slovensku v době tzv. studené války. V podobném časovém období pracoval v Čechách režisér Jiří Svoboda, který se svým častým spolupracovníkem - scénografem Oldřichem Šimáčkem - vytvořil také několik inscenací dramatických her Williama Shakespeara. Jaké hry to byly, jak jejich realizace vypadaly a čím se vyznačoval scénografický rukopis Šimáčka ve spolupráci s režisérem Svobodou, vysvětlila svým příspěvkem Nad'a Satková z brněnské Masarykovy univerzity.

Po té vystoupila Věra Velemanová z Institutu umění - Divadelního ústavu v Praze, pojednávající ve své studii o inscenacích Hamleta v režii Miloše Horanského a v jevištním zpracování výtvarníků Vladimíra Nývlta a Libora Fáry.

$\mathrm{V}$ roce 1984 vytvořil Jaroslav Malina scénografické zpracování Shakespearovy komedie Sen noci svatojánské, která byla v režii Karla Kříže uvedena v Městských divadlech pražských. Tato inscenace se stala tématem příspěvku předposledního mluvčího, Julese Deeringa z University of London. Britský teatrolog představil svou prostorovou a textovou analýzu akční scénografie Jaroslava Maliny zmíněné inscenace a předal slovo posledním vystupujícím hullské konference. Jimi se stali američtí badatelé Joe Brandesky z Ohio State University a Sue Ott Rowlands z University of Northern Kentucky, kteří si společně připravili studii o skulpturální scénografické tvorbě Jaroslava Maliny pro Shakespearův Večer tř́králový a Richarda III.

Jejich vystoupením skončila konference v Hullu, díky níž zazněly příspěvky zabývající se sociálně-historickými, estetickými a technickými analýzami scénografických interpretací díla Williama Shakespeara v českých zemích a na Slovensku v období mezi lety 1840 a 2015. Konference Czech and Slovak Scenography for Shakespeare se uskutečnila jako první ze série cyklu, jehož pokračování se podle záměru organizátorů uskuteční na Masarykově univerzitě v Brně v listopadu 2016, později i na Ohio State University v USA.

DOI: 10.5817/TY2016-1-24 